\title{
Sirkuit Bola Keranjang: Permainan untuk Meningkatkan Kemampuan Motorik Kasar Anak Usia Dini
}

\author{
Pahendra' ${ }^{1}$, Hadija Selman ${ }^{2}$, Rohmiati ${ }^{3}$,Hasmira Said ${ }^{4}$, Umalya Sasnita ${ }^{5}$, Nasir 6 , Tri Indah \\ Rusli7 ${ }^{凶}$ \\ Pendidikan Guru Anak Usia Dini, Universitas Muhammadiyah Kendari( $(1,2,3,4,5)$ \\ Administrasi Pendidikan, Universitas Muhammadiyah Kendari(6) \\ Pendidikan Bahasa Inggris, Universitas Muhammadiyah Kendari(7) \\ DOI: $10.31004 /$ obsesi.v5i2.1077
}

\begin{abstract}
Abstrak
Kegiatan belajar di Pendidikan Anak Usia Dini (PAUD) saat ini lebih banyak memanfaatkan alat atau teknologi kekinian yang minim aktifitas fisik. Akibatnya motorik anak kurang terlatih. Oleh karena itu, penelitian ini bertujuan untuk meningkatkan kemampuan motorik kasar anak usia dini melalui permaian sirkuit bola keranjang. Studi dilakukan di Kelompok B Taman Kanak-kanak Napabale Kelurahan Lalodati Kecamatan Puuwatu, Kota Kendari. Peneliti menerapkan prosedur penelitian tindakan. Nilai PAP 75\% dijadikan sebagai standar keberhasilan secara klasikal. Tindakan dilakukan dalam 2 siklus, masing-masing siklus terdiri dari 2 pertemuan dan evaluasi hasil belajar. Hasil penelitian didapati permainan bola keranjang berhasil meningkatkan kemampuan motorik kasar anak usia dini. Permainan ini memenuhi prinsip-prinsip sebuah permainan sebagai media belajar di Pendidikan PAUD.
\end{abstract}

Kata Kunci: paud; permainan edukatif; sirkuit bola keranjang

\begin{abstract}
Early Childhood Education learning activities are currently incorporating more advanced instruments or technologies and little physical exercise. As a consequence, the child's motor functions are poorly trained. Yet, this research attempts to develop early childhood gross motor abilities by playing a basketball circuit. The study was conducted in Napabale Kindergarten Group B, Lalodati Village, District of Puuwatu, Kendari. Action research procedures were implemented by researchers. As the classical criterion of performance, a PAP value of 75 percent has been used. The action is carried out in two stages, each cycle consisting of two meetings and a learning outcome assessment. The findings revealed that playing basketball was effective in developing early childhood gross motor skills. For PAUD Schooling, this game fulfils the ideals of a game as a learning platform.
\end{abstract}

Keywords: basketball circuit; early childhood education; educational games

Copyright (c) 2021 Pahendra, Hadija Selman, Rohmiati, Hasmira Said, Umalya Sasnita, Nasir, Tri Indah Rusli

$\triangle$ Corresponding author:

Email Address: Tri.indahrusli@umkendari.ac.id (Kendari, Sulawesi Tenggara, Indonesia)

Received 22 January 2021, Accepted 9 February 2021, Published 11 February 2021 


\section{PENDAHULUAN}

Permendikbud Nomor 146 Tahun 2014 pasal 5 tentang Kurikulum 2013 Pendidikan Anak Usia Dini, menyebutkan bahwa salah satu aspek yang wajib dikembangkan dari anak sejak usia dini adalah keterampilan motorik kasar. Motorik kasar (gross motor skill) adalah keterampilan yang mengasah aktivitas otot besar. Novitasari, $d k k .$, (2019) menyebutkan jika aspek-aspek pokok dalam pembelajaran motorik kasar pada anak adalah kekuatan, daya tahan kardiovaskuler (ketahanan), power, kecepatan, ketahanan, kelincahan, keseimbangan, waktu reaksi dan koordinasi. Keterampilan motorik merupakan aktifitas jasmani melalui kegiatan pusat syaraf, urat syaraf dan otot yang terkoordinasi yang sangat penting dalam pertumbuhan dan perkembangan anak usia dini, sehingga melatih atau membiasakan keterampilan motorik kasar anak melalui permainan kreatif merupakan tahapan dalam mendukung tumbuh kembangnya (Apriloka, 2020). Dengan porsi yang terukur, manfaat melatih motorik kasar anak yaitu menurunkan resiko obesitas, meningkatkan kebugaran (Cheng $d k k ., 2016$ ), self dan awareness dengan lingungan sekitar anak (Ningtyas \& Risina, 2018).

Lebih lanjut, Permendikbud Nomor 137 Tahun 2014 tentang Standar Nasional Pendidikan Anak Usia Dini Pasal 8 mengenai Standar Tingkat Pencapaian Perkembangan, menyebutkan bahwa perkembangan motorik kasar anak usia 5-6 tahun yaitu: 1) melakukan gerakan tubuh secara terkoordinasi untuk melatih kelenturan, keseimbangan, dan kelincahan; 2) melakukan koordinasi gerakan mata-kaki-tangan-kepala dalam menirukan tarian atau senam; 3) melakukan permainan fisik dengan aturan; 4) terampil menggunakan tangan kanan dan kiri; 5) Melakukan kegiatan kebersihan diri. Aktivitas fisik bagi anak menjadi penting karena melalui aktivitas tersebut, mereka akan berlatih mengembangkan kemampuan motorik kasarnya (Novitasari et al., 2019). Akan tetapi, kemajuan teknologi telah mengambil alih aktifitas fisik anak. Pembelajaran yang diterapkan guru hanya fokus pada pengembangan aspek intelektual, akibatnya peserta didik kurang terlatih keterampilan motorik kasarnya. Berdasarkan evaluasi motorik kasar awal peneliti pada objek penelitian (Anak Kelompok B Taman Kanak-kanak Napabale Kota Kendari), hanya 33\% atau 5 anak yang memperoleh nilai BSB dan BSH.

Sulistyaningtyas \& Fauziah (2019) mengilustrasikan bahwa saat ini, dunia telah berada pada era perkembangan teknologi yang sangat pesat tidak terkecuali Indonesia. Banyak anak sejak dari balita telah terkonminasi oleh gadget seperti HP, tablet, dan laptop. Hasil survey menyatakan bahwa persentase anak berusia 5 tahun ke atas yang pernah mengakses internet dalam 3 bulan terakhir pada tahun 2015 di daerah perkotaan mengalami peningkatan dari $25,84 \%$ menjadi $32.04 \%$. Hal tersebut juga terjadi di daerah pedesaan yang mengalami peningkatan dari 8,37\% menjadi 11,70\% (Badan Pusat Statistik, 2013). Temuan Mutema, (2013), juga menyebutkan bahwa sekitar $80 \%$ dari 50 subjek penelitiannya menghabiskan waktu untuk menonton TV. Survei Data Global Web Index, menempatkan Indonesia sebagai Negara yang memiliki pengguna sosial media yang paling aktif di asia. 79,7\% user aktif di sosial media, mengalahkan Filipina 78\%, Malaysia 72\%, dan Cina 67\%. Di samping itu, data statistik perkembangan internet di Indonesia mencapai $15 \%$ atau 38,191,873 pengguna internet dari total populasi 251,160,124 jiwa.

Keberadaan gadget memiliki dampak negatif bagi anak usia dini. Oleh karena itu, pendampingan dialogis dari orang tua yang berguna untuk mengurangi mereka dari kecanduan penggunaan gadget mutlak diperlukan. Anak perlu dilatih agar mereka tetap senang berinteraksi dan membuat aktifitas fisik di lingkungan sekitarnya. Penelitian terdahulu, secara umum membuktikan bahwa aktivitas fisik, bermanfaat bagi anak. Permainan dengan aktifitas fisik secara signifikan mempengaruhi kemampuan motorik kasar, melatih toleransi, dan sikap kooperatif anak (Ramdani \& Azizah, 2019), bahkan aktivitas fisik yang terukur pada anak-anak mencegah penyakit tidak menular kronis jangka panjang (Hernandez-Rincon dkk., 2018). 


\section{METODOLOGI}

Penelitian ini merupakan penelitian tindakan (action research), karena peneliti menekankan pada inkuiri (Manfra, 2019), serta menempatkan guru dan anak didik sebagai subyek penelitian. Tahapan pelaksanaan penelitian ini dilakukan dalam 2 siklus, yang masing-masing siklus terdiri dari kegiatan: perencanaan, pelaksanaan tindakan, pengamatan dan refleksi. Dsain penelitian tindakan ini ditunjukkan dalam Gambar 1.

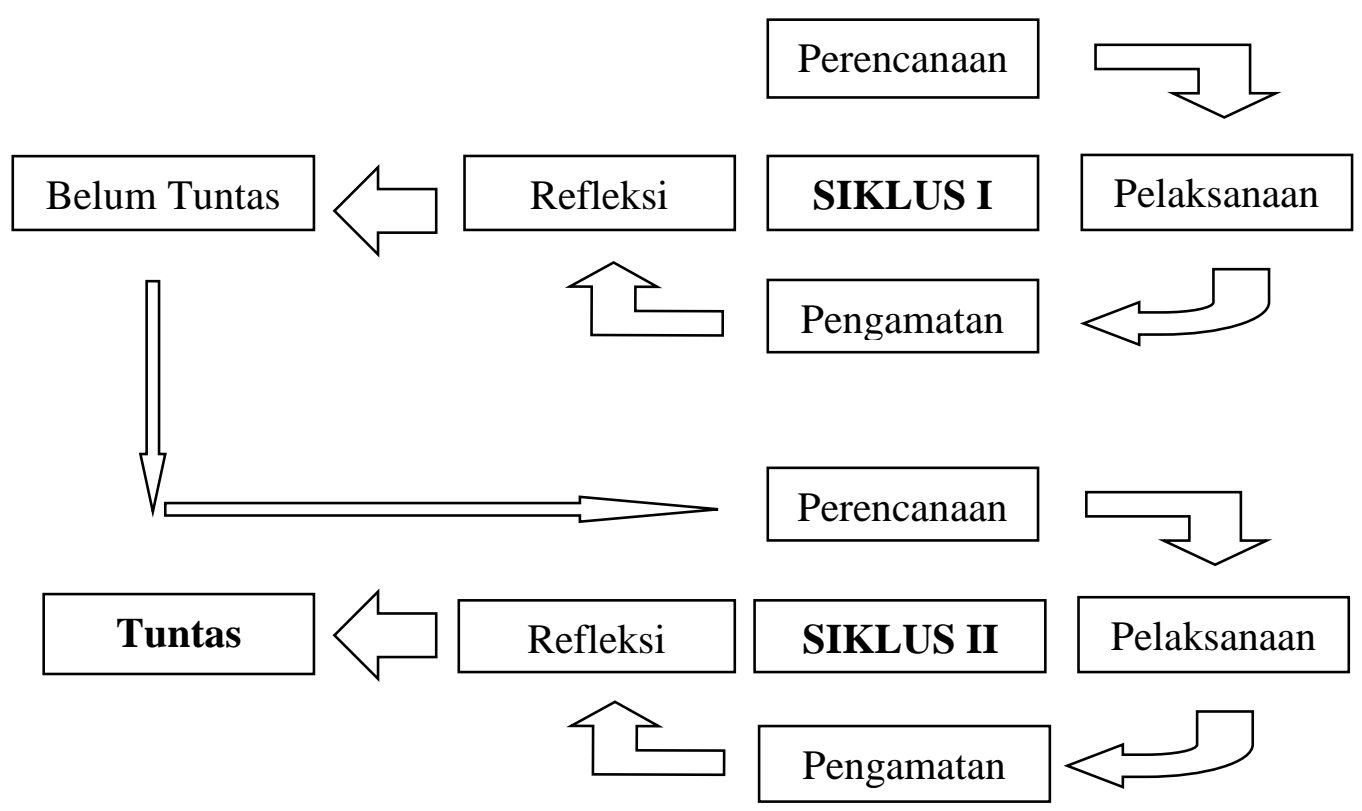

Gambar 1. Desain Penelitian Tindakan (Arikunto, 2010)

Studi dilakukan di Kelompok B Taman Kanak-kanak Napabale Kota Kendari Jln. Doktor Sutomo Kelurahan Lalodati Kecamatan Puuwatu. Pengumpulan data (observasi kolaboratif, dan analisa dokumen) dilakukan pada bulan November sampai bulan Desember 2019 Tahun Pelajaran 2019/2020. Dalam kegiatan analisis data, peneliti melakukan perhitungan terhadap jumlah seluruh nilai perolehan anak dengan penjelasan langkahlangkah penilaian dan formulasi analisis data, yang langkah-langkahnya adalah: 1) Melakukan penilaian dengan menggunakan format penilaian simbol (yang didalamnya terdapat sejumlah indikator yang diamati/dinilai selama proses kegiatan anak sedang berlangsung. Indikator yang ditetapkan sebagai bahan untuk kegiatan penilaian dan analisis data seluruhnya berjumlah 7 indikator; 2) Kegiatan selanjutnya mengitung jumlah atau frekuensi masing-masing nilai perolehan BSB, BSH, MB, BB, yang berhasil diraih anak didik dalam tahap kegiatan evaluasi, dengan pemberian bobot nilai 4,3,2,1; dan 3) Setelah pemberian bobot, lalu dilakukan analisis perhitungan bobot seluruh jumlah nilai perolehan ketentuan anak dalam kegiatan evaluasi untuk memberi nilai akhir setiap kegiatan anak didik dari hasil kegiatan.

Ketentuan perolehan nilai (secara individu) dengan kriteria hasil hitungan berdasarkan konversi anak pada tabel 1.

Tabel 1. Ketentuan perolehan nilai dengan kriteria hasil hitungan berdasarkan konversi anak

\begin{tabular}{lll}
\hline No. & \multicolumn{1}{c}{ Kriteria } & Indikator \\
\hline $\mathbf{1}$ & BSB (berkembang sangat baik/tuntas) & jika hasil hitungan akhir antara 3,50-4,00 \\
$\mathbf{2}$ & BSH (berkembang sesuai harapan/tuntas) & jika hasil hitungan akhir antara 2,50-3,49. \\
$\mathbf{3}$ & MB (mulai berkembang/belum tuntas) & jika hasil hitungan akhir antara 1,50-2,49. \\
$\mathbf{4}$ & BB (belum berkembang/belum tuntas) & jika hasil hitungan akhir antara 0,01-1,49. \\
\hline
\end{tabular}


Analisis perhitungan untuk nilai akhir setiap anak dilakukan dengan formulasi persentase bobot jumlah perolehan nilai anak sebagai berikut:

$$
\text { Perolehan Nilai Akhir Anak }=\frac{(\mathrm{JN} \text { BSB X 4) }+(\mathrm{JN} \text { BSH X 3) }+ \text { JN MB X 2) }+(\text { JN BB X 1) }}{\text { Jumlah indikator }}
$$

Selanjutnya disesuaikan dengan indikator kinerja yang digunakan untuk mengetahui keberhasilan kinerja secara klasikal pada setiap siklus tindakan, dalam penelitian ini menggunakan penelitian acuan patokan $75 \%$ secara klasikal dengan formulasi sebagai berikut:

$$
\text { Nilai Persen }=\frac{\text { Jumlah anak yang memperoleh }(\text { BSH }+ \text { BSB })}{\text { Jumlah anak didik }} \times 100
$$

Indikator penilaian kemampuan motorik anak meliputi: 1) Kemampuan anak dalam melempar satu tangan; 2) Melempar dua tangan; 3) Memasukkan bola kedalam keranjang dengan satu tangan; 4) memasukkan bola kedalam keranjang dengan dua tangan; 4) Melompat dengan satu kaki; 5) melompat dengan dua kaki; 6) Berlari seimbang tanpa jatuh 7) Berlari sambil membawa bola ditangan; dan 8) Memasukkan bola kedalam keranjang dengan jarak 3 meter.

\section{HASIL DAN PEMBAHASAN}

\section{Analisis Situasi dan Perencanaan Pembelajaran}

Tahapan pertama yang dilakukan peneliti yaitu melakukan serangkaian observasi awal, koordinasi, dan pertemuan bersama guru. Berdasarkan hasil observasi dan pertemuan tersebut, peneliti dan guru merefleksi bahwa berbagai pendekatan dan metode pembelajaran telah diterapkan pada anak didik, tetapi hasilnya belum mampu meningkatkan kemampuan motorik kasar anak. Hal tersebut diakibatkan karena pembelajaran yang diselenggarakan guru cenderung kaku, dan belum ada pengembangan sebuah strategi pendekatan belajar yang inovatif. Oleh karena itu, tim peneliti bersama guru berusaha merancang suatu bentuk kegiatan yang menarik dan menyenangkan bagi anak untuk meningkatkan kemampuan motorik kasar. Kegiatan tersebut yaitu belajar melalui permainan sirkuit bola keranjang.

Tahapan selanjutnya, peneliti bersama-sama dengan guru menyusun Rencana Pelaksanaan Pembelajaran Harian (RPPH). RPPH tersebut berisi: 1) waktu pelaksanaan kegiatan; 2) tujuan pembelajaran; 3) metode; 4) media; 5) sumber belajar yang digunakan serta ditetapkan jumlah anak didik yang akan dijadikan subjek penelitan; dan 6) menyusun instrumen penilaian kemampuan anak didik, pedoman observasi dan dokumentasi selama kegiatan observasi (peneliti).

Prosedur penelitian disusun dan disesuaikan dengan jadwal yang telah disusun; sebanyak dua siklus (karena nilai PAP sudah melampui 75\%). Masing-masing siklus terdiri dari 2 kali pertemuan dengan materi yang sama, yaitu: meningkatkan kemampuan motorik kasar anak melalui permainan sirkuit bola keranjang. Selanjutnya, paparan temuan berkenaan pelaksanaan pembelajaran pada kelas subjek meliputi deskripsi hasil pelaksanaan tindakan siklus I dan siklus II. Tabel 1. merupakan perencanaan dan deskripsi kegiatan pada masingmasing siklus. Peneliti bersama guru merencanakan 2 pertemuan pada masing-masing siklusnya. Pada masing-masing siklus beberapa hal yang harus dipersiapkan guru, yaitu: $\mathrm{RPPH}$, sirkuit ban, intrumen penilaian dan lembar observasi.

\section{Sirkuit Bola Keranjang}

Pada dasarnya, sirkuit bola keranjang adalah modifikasi dari permainan bolabasket; permainan yang dimainkan secara tim yang setiap tim terdiri dari 5 orang, sehingga diperlukan suatu kerjasama tim dan keterampilan dari masing-masing individu (Perdima, 2019). Sebagai suatu permainan, sirkuit bola keranjang dapat dijadikan sebagai alternatif yang 
Sirkuit Bola Keranjang: Permainan untuk Meningkatkan Kemampuan Motorik Kasar Anak Usia Dini

DOI: $10.31004 /$ obsesi.v4i2.1077

membantu anak untuk meningkatkan motorik mereka karena terdapat tugas gerak yang menyenangkan.

Tabel 1. Perencanaan dan Deskripsi Kegiatan pada Masing-Masing Siklus

\begin{tabular}{|c|c|c|c|}
\hline \multirow{2}{*}{\multicolumn{2}{|c|}{$\begin{array}{c}\text { Tahapan } \\
\text { Perencanaan di } \\
\text { Setiap Siklus }\end{array}$}} & \multicolumn{2}{|c|}{ Pelaksanaan Tindakan } \\
\hline & & Pertemuan I & Pertemuan II \\
\hline & $\begin{array}{l}\text { Membuat } \\
\text { rencana } \\
\text { pelaksanaan } \\
\text { pembelajaran } \\
\text { harian }(\mathrm{RPPH}) \\
\text { pertemuan I } \\
\text { sampai } \\
\text { pertemuan II }\end{array}$ & $\begin{array}{l}\text { Pada tahap ini, tindakan penelitian } \\
\text { dilaksanakan di halaman sekolah. } \\
\text { Kegiatan pembelajaran pada tindakan } \\
\text { siklus I pertemuan I diawali dengan } \\
\text { kegiatan pembukaan; guru memberi } \\
\text { salam dan berdoa bersama, lalu guru } \\
\text { melakukan gerakan } \\
\text { pemanasan sebelum kegiatan dimulai }\end{array}$ & $\begin{array}{l}\text { Pelaksanaan tindakan siklus I } \\
\text { pertemuan I telah dilaksanakan dan } \\
\text { belum menampakkan hasil } \\
\text { maksimal, maka dilanjutkan pada } \\
\text { pertemuan II. Kegiatan } \\
\text { pembelajaran pada tindakan siklus } \\
\text { I pertemuan II diawali dengan } \\
\text { kegiatan pembukaan; yakni guru }\end{array}$ \\
\hline & $\begin{array}{l}\text { Menyiapkan } \\
\text { media } \\
\text { pembelajaran, } \\
\text { alat dan bahan } \\
\text { untuk permainan } \\
\text { sirkuit bola } \\
\text { keranjang. }\end{array}$ & $\begin{array}{l}\text { (Gambar 2). Selanjutnya mempersiapkan } \\
\text { ban sebanyak } 6 \text { ban (Gambar 3), guru } \\
\text { menyiapkan } 2 \text { buah keranjang yang } \\
\text { berisi bola dan } 1 \text { keranjang untuk tempat } \\
\text { dimasukkan bola kemudian } 2 \text { anak } \\
\text { berdiri di posisi star sambil mendengar } \\
\text { aba-aba dari guru. Selanjutnya, anak }\end{array}$ & $\begin{array}{l}\text { memberi salam dan berdoa } \\
\text { bersama. Guru mempersiapkan ban } \\
\text { sebanyak } 6 \text { ban, } 2 \text { buah keranjang } \\
\text { yang berisi bola dan } 1 \text { keranjang } \\
\text { untuk tempat memasukkan bola } \\
\text { kemudian } 2 \text { anak berdiri diposisi } \\
\text { star sambil mendengar aba-aba dari }\end{array}$ \\
\hline & $\begin{array}{l}\text { Membuat lembar } \\
\text { observasi } \\
\text { aktivitas } \\
\text { mengajar guru } \\
\text { selama proses } \\
\text { belajar mengajar } \\
\text { berlangsung. }\end{array}$ & $\begin{array}{l}\text { mengambil bola yang ada didalam } \\
\text { keranjang lalu berlari melewati ban } \\
\text { (Gambar 5) yang telah dibuat sirkuit } \\
\text { dengan melompat dua kaki. Anak akan } \\
\text { berlari lalu, melompat dengan satu kaki } \\
\text { (Gambar 6). Selanjutnya anak melempar } \\
\text { bola untuk dimasukkan kedalam }\end{array}$ & $\begin{array}{l}\text { guru. Selanjutnya anak mengambil } \\
\text { bola yang ada di dalam keranjang } \\
\text { lalu berlari melewati ban (Gambar } \\
\text { 4) yang telah dibuat sirkuit dengan } \\
\text { melompat dua kaki. Dan anak akan } \\
\text { berlari lalu melompat dengan satu } \\
\text { kaki selanjutnya melempar bola, }\end{array}$ \\
\hline & $\begin{array}{l}\text { Membuat lembar } \\
\text { observasi } \\
\text { aktivitas } \\
\text { mengajar anak } \\
\text { selama proses } \\
\text { belajar mengajar } \\
\text { berlangsung. }\end{array}$ & $\begin{array}{l}\text { keranjang (Gambar } 4 \text { ). } \\
\text { Kegiatan penutup yaitu mendiskusikan } \\
\text { tentang kegiatan sehari dan } \\
\text { menginformasikan kegiatan besok, } \\
\text { salam, berdoa. } \\
\text { Pembelajaran pada tindakan siklus I } \\
\text { pertemuan I anak belum mampu }\end{array}$ & $\begin{array}{l}\text { dimasukkan kedalam keranjang. } \\
\text { Setalah semua anak melakukan } \\
\text { kegiatan permainan sirkuit bola } \\
\text { keranjang maka guru langsung } \\
\text { masuk pada kegiatan penutup } \\
\text { yaitu mendiskusikan tentang } \\
\text { kegiatan sehari dan }\end{array}$ \\
\hline 5. & $\begin{array}{l}\text { Membuat } \\
\text { instrument } \\
\text { penilaian } \\
\text { meningkatkan } \\
\text { kemampuan } \\
\text { motorik kasar } \\
\text { anak melalui } \\
\text { permainan } \\
\text { sirkuit bola } \\
\text { keranjang. }\end{array}$ & $\begin{array}{l}\text { menampakkan kemampuan motorik } \\
\text { kasar anak didik melalui permainan } \\
\text { sirkuit bola keranjang misalnya pada } \\
\text { saat melempar bola tanpa anak-anak } \\
\text { melaksanakan dengan berbagai cara ada } \\
\text { yang melempar bola terlalu pelan, ada } \\
\text { juga yang melempar bola terlalu keras } \\
\text { sehingga melewati keranjang, pada saat } \\
\text { anak mengangkat satu kaki anak belum } \\
\text { dapat menyeimbangi tubuhnya. Sesuai } \\
\text { kenyataan anak-anak melakukan } \\
\text { permainan sirkuit bola keranjang } \\
\text { tampak sangat riang dan penuh } \\
\text { semangat walaupun sebagian anak } \\
\text { belum bisa melakukan permainan } \\
\text { dengan baik, tetapi secara umum } \\
\text { permainan sirkuit bola keranjang sangat } \\
\text { menyenangkan kali ini tampak dari } \\
\text { eksperi wajah anak-anak dan dari hasil } \\
\text { belajar sesuai indikator penilaian. }\end{array}$ & $\begin{array}{l}\text { menginformasikan kegiatan besok, } \\
\text { salam, berdoa. Dalam pembelajaran } \\
\text { pada tindakan siklus I pertemuan II } \\
\text { masih ada anak didik yang gerakan } \\
\text { melempar belum terkoordinasi } \\
\text { antara mata dan tangan, pada saat } \\
\text { anak mengangkat satu kaki anak } \\
\text { belum mampu menyeimbangi } \\
\text { tubuhnya dan anak masih } \\
\text { memerlukan bantuan guru. Tetapi } \\
\text { suasana di halaman sekolah tampak } \\
\text { sangat riang dan menyenangkan } \\
\text { pada saat anak melakukan kegiatan } \\
\text { permainan sirkuit bola keranjang. }\end{array}$ \\
\hline
\end{tabular}


Penelitian terdahulu menunjukkan berbagai permainan sirkuit, ada pengaruh dengan kemampuan fisik motorik kasar (sirkuit geometry fun). Pada permainan sirkuit mahkota, memanfaatannya pada pembelajaran anak usia dini adalah sebagai strategi untuk meningkatkan motorik halus (Arie Paramitha \& Sutapa, 2019), dan keterampilan motorik kasar anak dengan autism (Komarisa, 2020). Melalui observasinya, siswa menjadi aktif dalam melakukan berbagai aktivitas, lebih tertarik dalam kegiatan belajar mengajar, tidak merasa bosan selama proses pembelajaran, dan permainan sirkuit sesuai dengan karakteristik anak dengan autisme karena berbasis visual.

Beberapa dokumentasi kegiatan anak dan guru pada pembelajaran melalui permainan bola sirkuit dapat dilihat pada gambar 2-6.

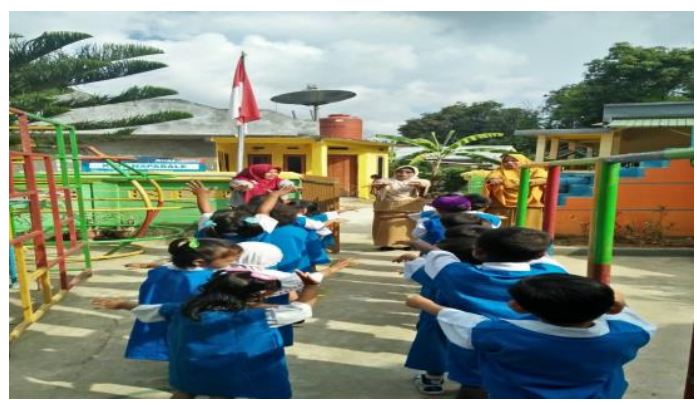

Gambar 2. Melakukan gerakan pemanasan sebelum kegiatan dimulai

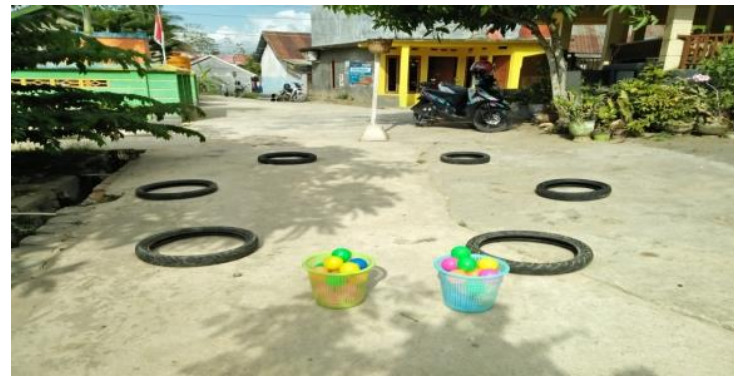

Gambar 3. Persiapan Sebelum Permainan Sirkuit Bola Keranjang Dimulai

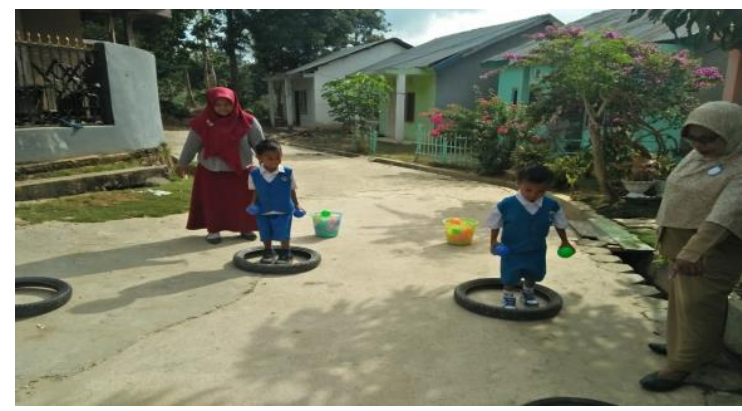

Gambar 5. Anak Melewati Sirkuit Ban

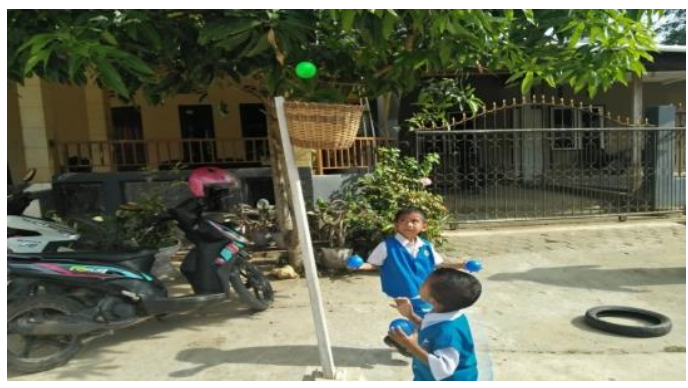

Gambar 4. Anak Memasukan Bola ke Keranjang

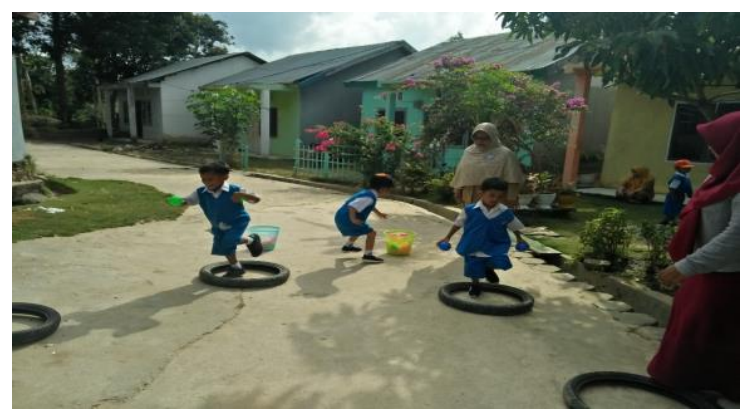

Gambar 6. Anak Melompat dengan Satu Kaki

\section{Hasil Observasi dan Penilaian pada Masing-Masing Siklus}

Pengolahan data observasi dengan pemberian nilai berdasarkan Penilaian Acuan Patokan (PAP). Tujuannya agar diketahui hasil dari penelitan ini. Dalam melakukan PAP, maka harus ditetapkan dulu standar nilai yang akan digunakan sebagai patokan pembanding terhadap hasil pengukuran (Suyanto, 2005). Nilai patokan ini merupakan batas penentuan keberhasilan atau tingkat penguasaan minimum. Patokan minimal 75\% ini bersifat tetap dan 
Sirkuit Bola Keranjang: Permainan untuk Meningkatkan Kemampuan Motorik Kasar Anak Usia Dini

DOI: 10.31004/obsesi.v4i2.1077

dapat juga digunakan untuk kelompok lain (Sudjana, 1995: 8) untuk mengukur keefektifan metode yang diterapkan oleh guru dalam kegiatan pembelajaran.

Tabel 2 Derajat Pemberian Bobot

\begin{tabular}{|c|c|c|}
\hline $\begin{array}{l}\text { Bobot (Bintang }= \\
\quad \text { Nilai) }\end{array}$ & Penilaian & Indikator/Tindakan \\
\hline$\star * * *=4$ & $\begin{array}{c}\text { Berkembang } \\
\text { sangat baik (BSB) }\end{array}$ & $\begin{array}{l}\text { Anak mampu melakukan kegiatan sesuai dengan } \\
\text { petunjuk dan melebihi indikator yang di harapkan }\end{array}$ \\
\hline$* * *=3$ & $\begin{array}{c}\text { Berkembang } \\
\text { Sesuai Harapan } \\
\text { (BSH) }\end{array}$ & $\begin{array}{l}\text { Anak menampakkan kemampuan motorik kasar } \\
\text { sesuai indikator tanpa dibimbing }\end{array}$ \\
\hline$* *=2$ & $\begin{array}{l}\text { Mulai Berkembang } \\
\text { (MB) }\end{array}$ & Masih Dibimbing/Diarahkan \\
\hline$*=1$ & $\begin{array}{c}\text { Belum } \\
\text { Berkembang (BB) }\end{array}$ & $\begin{array}{l}\text { Masih harus dibimbing secara langsung dan masih } \\
\text { selalu dibantu oleh guru }\end{array}$ \\
\hline
\end{tabular}

Nilai PAP (75\%) dijadikan sebagai standar keberhasilan secara klasikal. Artinya, jika $75 \%$ anak memperoleh nilai 75 (standar sekolah) atau melebihi, maka penerapan sirkuit bola keranjang dinyatakan telah berhasil. Selanjutnya, peneliti juga menetapkan derajat pemberian bobot $(4,3,2$, dan 1). Penerapan bobot tersebut, disesuikan dengan penilaian hasil kegiatan anak yang berlaku di Taman Kanak-Kanak.

Setelah kegiatan belajar dengan permainan sirkuit bola keranjang selesai, selanjutnya dilakukan evaluasi hasil, sebagaimana disajikan pada Tabel 3.

Tabel 3. Perolehan Nilai Ketuntasan Secara Klasikal

\begin{tabular}{|c|c|c|c|c|c|c|}
\hline \multirow[b]{2}{*}{ Indikator Evaluasi } & \multicolumn{3}{|c|}{ Siklus I } & \multicolumn{3}{|c|}{ Siklus II } \\
\hline & $\begin{array}{l}\text { Frekuensi } \\
\text { (jumlah } \\
\text { anak) }\end{array}$ & $\%$ & Kriteria & $\begin{array}{l}\text { Frekuensi } \\
\text { (jumlah } \\
\text { anak) }\end{array}$ & $\%$ & Kriteria \\
\hline $\begin{array}{l}\text { Anak yang memperoleh nilai } \\
\text { ketuntasan akhir “Berkembang } \\
\text { Sangat Baik" (BSB) }\end{array}$ & 0 & $0 \%$ & Tuntas & 2 & $14 \%$ & Tuntas \\
\hline $\begin{array}{l}\text { Anak yang memperoleh nilai } \\
\text { ketuntasan akhir "Berkembang } \\
\text { Sesuai Harapan" (BSH) }\end{array}$ & 8 & $53 \%$ & Tuntas & 10 & $66 \%$ & Tuntas \\
\hline $\begin{array}{l}\text { Anak yang memperoleh nilai } \\
\text { ketuntasan akhir "Mulai } \\
\text { Berkembang"(MB) }\end{array}$ & 6 & $40 \%$ & $\begin{array}{l}\text { Belum } \\
\text { Tuntas }\end{array}$ & 3 & $20 \%$ & $\begin{array}{l}\text { Belum } \\
\text { Tuntas }\end{array}$ \\
\hline $\begin{array}{l}\text { Anak yang memperoleh nilai } \\
\text { ketuntasan akhir "Belum } \\
\text { Berkembang"(BB) }\end{array}$ & 1 & $7 \%$ & $\begin{array}{l}\text { Belum } \\
\text { Tuntas }\end{array}$ & 0 & $0 \%$ & $\begin{array}{l}\text { Belum } \\
\text { Tuntas }\end{array}$ \\
\hline $\begin{array}{l}\text { Jumlah seluruh anak didik } \\
\text { kelompok B }\end{array}$ & 15 & $\begin{array}{c}100 \\
\%\end{array}$ & - & 15 & $100 \%$ & - \\
\hline $\begin{array}{l}\text { Presentase keberhasilan secara } \\
\text { klasikal jumlah anak yang tuntas } \\
\text { (BSB dan BSH) }\end{array}$ & 8 & & $53 \%$ & 12 & & $80 \%$ \\
\hline $\begin{array}{l}\text { Jumlah presentase anak yang } \\
\text { belum tuntas }\end{array}$ & 7 & & $47 \%$ & 3 & & $20 \%$ \\
\hline
\end{tabular}

Sumber: Hasil analisis data PTK, Tahun 2020. 
Pada siklus I, data pada Tabel di atas menunjukkan bahwa secara klasikal kegiatan dalam rangka meningkatkan kemampuan motorik kasar anak melalui permainan sirkuit bola keranjang pada tahap evaluasi siklus I, anak yang memperoleh nilai bintang 4 (****/Berkembang Sangat Baik) berjumlah 0 anak atau sebesar $0 \%$. Anak yang memperoleh bintang $3(* * * /$ Berkembang Sesuai Harapan) berjumlah 8 anak atau sebesar 53\%. Anak yang memperoleh nilai bintang $2(* * /$ Mulai Berkembang) berjumlah 7 anak atau sebesar $40 \%$, dan anak yang memperoleh nilai bintang 1 (*/Belum Berkembang) berjumlah 1 anak atau sebesar $7 \%$. Jadi berdasarkan perolehan nilai anak didik yang ditampilkan pada Tabel 1, dinyatakan bahwa kegiatan dalam rangka meningkatkan kemampuan motorik kasar anak melalui permainan sirkuit bola keranjang pada siklus I pertemuan I dan pertemuan II mencapai tingkat keberhasilan sebesar 53\%. Berdasarkan indikator keberhasilan yang ditetapkan sebesar $75 \%$ maka tindakan siklus I pertemuan I dan pertemuan II yang dilaksanakan dikatakan belum terselesaikan dan hal ini akan dilanjutkan ketahapan siklus selanjutnya yaitu siklus II.

Pada Siklus II, data pada Tabel 2 bahwa secara klasikal perolehan nilai anak didik dalam meningkatkan kemampuan motorik kasar anak dengan permainan sirkuit bola keranjang, mengalami peningkatan. Anak dengan nilai bintang 4 (****BSB/Berkembang Sangat Baik) berjumlah 2 orang atau sekitar 14\%, anak dengan nilai bintang 3 (***BSH/Berkembang Sesuai Harapan) berjumlah 10 orang atau sekitar $66 \%$, dan anak dengan nilai bintang $2\left({ }^{* *} \mathrm{MB} /\right.$ Mulai Berkembang) berjumlah 3 orang atau sekitar 20\%. Sedangkan anak dengan nilai bintang 1 ( ${ }^{*} \mathrm{BB} /$ Belum Berkembang) tidak terdapat lagi pada siklus II.

\section{Refleksi}

Hasil penilaian kemampuan motorik kasar anak anak setelah tindakan siklus I adalah: masih terdapat beberapa kelemahan yang ditemui, misalnya masih ada anak yang belum mampu melompat satu kaki (harus dipegang tangannya oleh guru). Sedangkan secara klasikal, perolehan nilai keberhasilan mencapai 53\%. Melihat indikator keberhasilan yang ditetapkan (minimal 75\%), maka penelitian disiklus I belum terselesaikan. Oleh karena itu, peneliti bersama guru harus melaksanakan persiapan dalam membuat perencanaan untuk diperbaiki dan dilaksanakan pada siklus selanjutnya. Sementara itu, pada siklus II pertemuan I dan pertemuan II telah mencapai nilai $80 \%$. Artinya, indikator keberhasilan secara klasikal telah terpenuhi. Oleh karena itu, guru dan peneliti sepakat untuk tidak melanjutkan ketahap selanjutnya atau tindakan penelitian dihentikan.

Beberapa catatan (Tabel 4) yang dibuat oleh peneliti selama guru melakukan kegiatan belajar dengan permainan sirkuit bola keranjang meliputi faktor anak didik dan faktor guru.

\section{Pembahasan}

Permainan dipilih oleh peneliti dan guru sebagai "tindakan" untuk meningkatkan keterampilan motorik anak karena permainan adalah alat yang ampuh dalam pendidikan, karena melalui permainan anak-anak memperoleh pengetahuan, memperkaya pengalaman mereka, dan mengembangkan keterampilan dan kebiasaan. Permainan adalah bentuk hiburan yang penting untuk anak-anak dan bahkan orang dewasa melalui permainan, anak-anak berorganisasi secara mandiri (Petrovska et al., 2013).

Permainan sirkuit bola keranjang merupakan kreasi permainan antara guru dan peneliti. Merujuk pada taksonomi Spradley, permainan Sirkuit Bola Keranjang terdiri dari struktur hirarki sebagai dapat dilihat pada gambar 7.

Berdasarkan analisa peneliti, keberhasilan "tindakan" yang dipilih dalam meningkatkan keterampilan motorik anak disebabkan karena permainan sirkuit bola keranjang: Merupakan kegiatan di lingkungan sekitar anak; Mengikutsertakan hakikat, sifat dan karakteristik anak; Menawarkan permainan peran yang memungkinkan penegasan diri dan pengakuan diri; Bersifat dinamis; butuh reaksi intelektual yang cepat untuk menyelesaikan tugas; Menciptakan suasana hati yang baik; Mencakup aktivitas fisik, yang 
membutuhkan kerjasama, dan keterlibatan intelektual; serta Membawa anak-anak pada kegembiraan, perasaan bahagia dan puas, menikmati efek sinar matahari untuk daya tahan dan kekebalan tubuh.

Tabel 4. Kegiatan Pembelajaran siklus 1 dan II

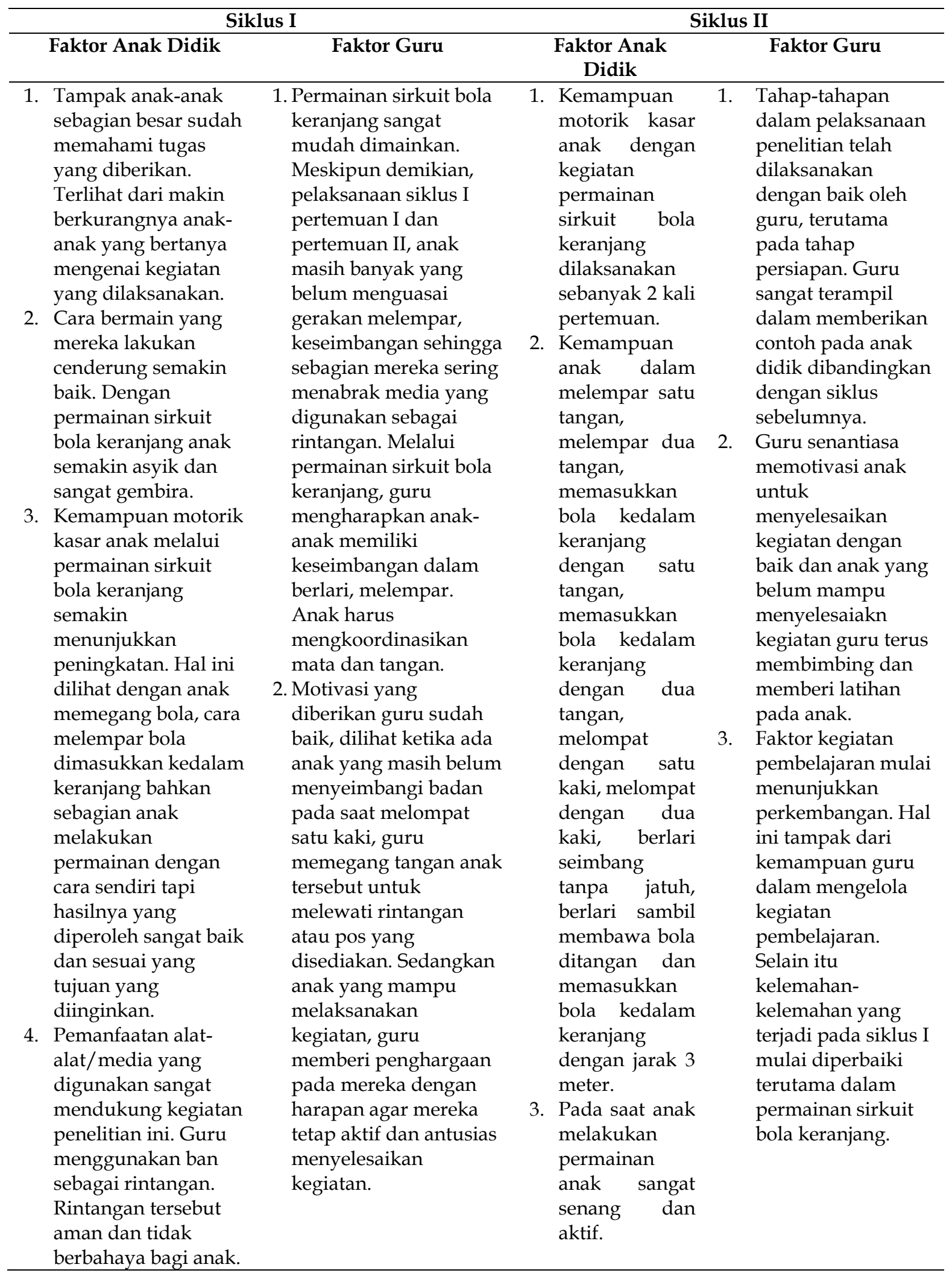




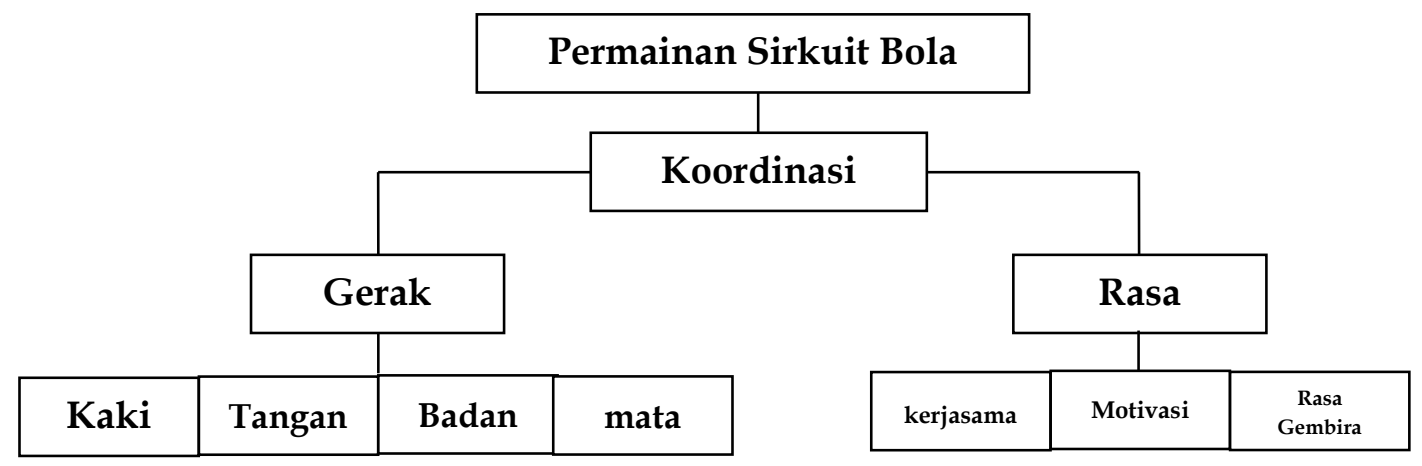

\section{Gambar 7. Struktur Hirarki Sirkuit Bola Keranjang sesuai Analisa Taksnomi Spradley}

Berdasarkan kepercayaan konsep belajar Montessori, kegiatan belajar pertama yang wajib diperkenalkan pada anak di kelas adalah materi yang tersusun dari kurikulum kehidupan praktis. Di samping membangun kontrol motorik kasar dan halus anak, permainan bagi anak usia dini juga berfungsi dalam pengaturan sosial kelas, dan mengembangkan keterampilan anak untuk hidup mandiri. Melalui sebuah permainan dengan gerak fisik, koordinasi mata-tangan terlatih (Marshall, 2017).

Permainan modern yang sekarang ini sering dimainkan oleh anak-anak di perkotaan lebih cenderung mengasah kemampuan otak daripada kemampuan otot. Oleh karena itu, orang tua yang tinggal di perkotaan disarankan lebih memperkenalkan anak-anak pada jenisjenis permainan yang lebih melatih kekuatan otot-otot mereka. Sebagaimana yang diuraikan Hasanah, permainan yang dilakukan merupakan sesuatu yang dianggap wajib dilakukan sebagai sarana untuk perkembangan fisik motorik bagi anak usia dini (Hasanah, 2016), membantu daya ingat siswa, meningkatkan keterampilan memecahkan masalah, melatih fokus anak dengan gangguan perhatian, dan mengajarkan mereka untuk patuh pada aturan (Zirawaga et al., 2017).

Untuk memenuhi kriteria permainan bagi anak usia dini, hal penting yang harus diperhatikan adalah mengenali dan menyesuaikan dengan karakter dan psikologi penggunanya. Hal ini perlu ditekankan karena anak berbeda dengan orang dewasa dalam berbagai aspek, seperti perkembangan fisik, sosial, dan kognitifnya (Sudarmilah, dkk., 2016).

Sementara itu, permainan sirkuit bola keranjang mengikutsertakan hakikat, sifat dan karakteristik anak. Sejalan dengan rumusan Direktorat Pembinaan Pendidikan Anak Usia Dini (2015) bahwa prinsip pembelajaran anak usia yaitu: belajar melalui bermain, berorientasi pada perkembangan anak, berorientasi pada kebutuhan anak, berpusat pada anak, pembelajaran aktif, berorientasi pada pengembangan nilai-nilai karakter.

\section{SIMPULAN}

Permainan bola keranjang berhasil meningkatkan kemampuan motorik kasar anak usia dini pada kelompok B Taman Kanak-kanak Napabale Kota Kendari. Faktor yang paling dominan karena permainan ini memenuhi prinsip-prinsip sebuah permainan sebagai media belajar anak pada PAUD. Prinsip-prinsip permainan sebagai media belajar yaitu: 1) merupakan kegiatan di lingkungan sekitar anak; 2) mengikutsertakan hakikat, sifat dan karakteristik anak; 3) menawarkan permainan peran yang memungkinkan penegasan diri dan pengakuan diri; 4) bersifat dinamis; 5) menciptakan suasana hati yang baik; 6) mencakup aktivitas fisik, yang membutuhkan kerjasama, dan keterlibatan intelektual; serta 7) membawa anak pada kegembiraan, perasaan bahagia dan puas, menikmati efek sinar matahari untuk daya tahan dan kekebalan tubuh. Dengan demikian permainan ini dapat dijadikan sebagai alternatif solusi dalam meningkatkan kemampuan motorik kasa pada anak usia dini. 


\section{UCAPAN TERIMA KASIH}

Tim peneliti mengucapkan terima kasih kepada semua pihak (Kepala sekolah, guru, dan anak didik) atas kesediaan dan kontribusinya sehingga penelitian berhasil terlaksana. Semua pihak yang telah membantu sehingga artikel ini dapat dipublikasikan.

\section{DAFTAR PUSTAKA}

Apriloka, D. V. (2020). Keterampilan Motorik Kasar Anak Usia Dini Ditinjau Dari Jenis Kelamin. (JAPRA) Jurnal Pendidikan Raudhatul Athfal (JAPRA), 3(1), 61-67. https://doi.org/10.15575/japra.v3i1.8106

Arie Paramitha, M. V., \& Sutapa, P. (2019). Pengembangan Model Pembelajaran Berbasis Permainan Sirkuit Untuk Meningkatkan Motorik Halus Anak Usia 4-5 Tahun. Jurnal Golden Age, 3(01), 1. https:/ / doi.org/10.29408/goldenage.v3i01.1336

Arikunto. (2010). Prosedur penelitian atau pendekatan praktik. Rineka Cipta.

Badan Pusat Statistik. (2013). Survei Sosial Ekonomi Nasional. Socio-Economic/Monitoring Survey, 1-112.

Cheng, J., East, P., Blanco, E., Kang Sim, E., Castillo, M., Lozoff, B., \& Gahagan, S. (2016). Obesity leads to declines in motor skills across childhood. Child: Care, Health and Development, 42(3), 343-350. https:/ / doi.org/10.1111/cch.12336

Direktorat Pembinaan Pendidikan Anak Usia Dini. (2015). Petunjuk Teknis Penyelenggaraan Taman Kanak-kanak.

Hasanah, U. (2016). Pengembangan Kemampuan Fisik Motorik Melalui Permainan Tradisional Bagi Anak Usia Dini. Jurnal Pendidikan Anak, 5(1), 717-733. https://doi.org/10.21831/jpa.v5i1.12368

Hernández-Rincón, E. H., Arias-Villate, S. C., Gómez-López, M. T., León-Pachón, L. E., Martínez-Ceballos, M. A., Chaar-Hernández, A. J., \& Severiche-Bueno, D. (2018). Physical activity from primary care oriented to the community for preschool children in a colombian municipality. Revista Cubana de Pediatria, 90(2), 201-212.

Kemendikbud. (2014). Permen Kemendikbud No. 146 Tahun 2014 Tentang Kurikulum 2013 Pendidikan Anak Usia Dini. Permen Kemendikbud, 2025(1679). https://portaldik.id/assets/upload/peraturan/PERMEN KEMENDIKBUD Nomor 146 Tahun 2014 KURIKULUM 2013 PENDIDIKAN ANAK USIA DINI.pdf

Komarisa, P. (2020). Permainan sirkuit sebagai Strategi untuk Meningkatkan Keterampilan Motorik Kasar Anak dengan Autisme [Universitas Negeri Surabaya]. https://jurnalmahasiswa.unesa.ac.id/index.php/jurnal-pendidikankhusus/article/view/35031/31167

Manfra, M. M. G. (2019). Action Research and Systematic, Intentional Change in Teaching Practice. In Review of Research in Education (Vol. 43, Nomor 1, hal. 163-196). https://doi.org/10.3102/0091732X18821132

Marshall, C. (2017). Montessori education: a review of the evidence base. npj Science of Learning, 2(1), 1-9. https://doi.org/10.1038/s41539-017-0012-7

Mutema, F. (2013). Shona Traditional Children's Games And Songs As A Form Of Indigenous Knowledge: An Endangered Genre. IOSR Journal Of Humanities And Social Science, 15(3), 59-64. https:/ / doi.org/10.9790/0837-1535964

Ningtyas, D. P., \& Risina, D. F. (2018). Pengembangan Permainan Sirkuit Mitigasi Bencana Gempa Bumi Untuk Meningkatkan Self Awareness Anak Usia Dini. Jurnal Caksana: Pendidikan Anak Usia Dini, 1(02), 172-187. https:// doi.org/10.31326/jcpaud.v1i02.198

Novitasari, R., Nasirun, M., \& D., D. (2019). Meningkatkan Kemampuan Motorik Kasar Anak Melalui Bermain Dengan Media Hulahoop Pada Anak Kelompok B PAUD AlSyafaqoh Kabupaten Rejang Lebong. Jurnal Ilmiah POTENSIA, 4(1), 6-12. https://doi.org/10.33369/jip.4.1.6-12

Perdima, F. E. (2019). Pengaruh Metode Latihan Sirkuit Dan Metode Konvensional Terhadap Keterampilan Dasar Bola Basket. Altius : Jurnal Ilmu Olahraga dan Kesehatan, 6(1), 1-6. 
https:// doi.org/10.36706/altius.v6i1.8221

Petrovska, S., Sivevska, D., \& Cackov, O. (2013). Role of the Game in the Development of Preschool Child. Procedia - Social and Behavioral Sciences, 92(October 2013), 880-884. https:// doi.org/10.1016/j.sbspro.2013.08.770

Ramdani, L. A., \& Azizah, N. (2019). Permainan Outbound untuk Perkembangan Motorik Kasar Anak Usia Dini. Jurnal Obsesi: Jurnal Pendidikan Anak Usia Dini, 4(1), 494. https:// doi.org/10.31004/obsesi.v4i1.407

Sudarmilah, E., Susanto, A., Ferdiana, R., \& Ramdhani, N. (2016). Developing a game for preschoolers: What character, emotion and reward will tend to hack preschoolers? Proceedings of 2015 International Conference on Data and Software Engineering, ICODSE 2015, February, 89-92. https:// doi.org/10.1109/ICODSE.2015.7436977

Sulistyaningtyas, R. E., \& Fauziah, P. Y. (2019). Pengembangan buku panduan permainan tradisional untuk meningkatkan kemampuan motorik kasar anak usia 5-6 tahun. JPPM (Jurnal Pendidikan dan Pemberdayaan Masyarakat), 6(1), 50-58. https:// doi.org/10.21831/jppm.v6i1.23477

Suyanto, S. (2005). Dasar-Dasar Pendidikan Anak Usia Dini. Hikayat.

Zirawaga, V., Olusanya, A., \& Maduki, T. (2017). Gaming in education: Using games a support tool to teach History. Journal of Education and Practice, 8(15), 55-64. https:// files.eric.ed.gov/fulltext/EJ1143830.pdf 